Милосав 3. Ђоковић

Балканолошки институт САНУ, Београд

e-mail:milosav.djokovic@bi.sanu.ac.rs

\title{
ВАТИКАНСКИ ДИПЛОМАТА ПАОЛО БЕРТОЛИ О ИЗБОРУ СРПСКОГ ПАТРИЈАРХА 1938. ГОДИНЕ
}

Апстракт: Након одласка апостолског нунција Пелегринетија из Београда, децембра 1937, управу ad interim над нунцијатуром у Југославији преузео је Паоло Бертоли, који је, као и Пелегринети, остављао своја запажања и утиске о многим дешавањима у иелој Краљевини, међу којима је свакако била и Српска православна црква. Најзначајнији догађај у току његове управе нунцијатуром био је и избор новог патријарха у фебруару 1938. године.

У раду се користе извештаји и дописи државном секретару Пачелију, као $и$ необјављена Бертолијева писма кардиналу Пелегринетију у Р Рим. У юима говори о изборном сабору СПЦ, о кандидатима и о личности новог патријарха Гаврила Дожића, у којима осетно провејава поприлично негативан став, свакако услед лоших односа са СПЦ изазваних питањем Конкордата.

Кључне речи: Паоло Бертоли, Гаврило Дожић, СПЦ, Ерменеђилдо Пелегринети, Милан Стојадиновић, ватиканско-југословенски односи

Паоло Бертоли (Paolo Bertoli) ${ }^{2}$ је иза себе имао неколико година дипломатске службе у нунцијатури у Југославији када је, децембра 1937, након одласка Ерменеђилда

1 Захваљујем се префекту Ватиканског апостолског архива монсињору Серђу Пагану (mons. Sergio Pagano), вицепрефекту Паолу Вијану (Paolo Vian) као и Алехандру Дијегесу (Alejandro Diesguez) на дозволи консултовања архивске грађе из заоставштине кардинала Пелегринетија која је у процесу сређивања.

Треба узети у обзир да се у раду приликом навођења писама Паола Бертолија из фонда кардинала Пелегринетија наводи само привремени број кутије (тј. број кутије где се ова писма привремено налазе). Будући да грађа није сређена нису навођени бројеви листова будући да још увек нису нумерисани. Приликом цитирања Бертолијевог текста на италијанском, у ноти дајемо и наш превод на српски језик.

2 Паоло Бертоли (Пођо Гарфањана, 1908 - Рим, 2001) надбискуп и кардинал Католичке цркве. Дипломатску службу започео је као чиновник, а потом и секретар нунцијатуре у Југославији (19331938). После Београда био је у дипломатској служби Свете Столице у: Француској (1938-1941), Хаитију (1942-1946), Швајцарској (1946-1949), Чехословачкој (1949-1952). Именован је за титуларног надбискупа никомидијског 24. марта 1952, а рукоположен 11. маја исте године у Риму. Био је апостолски делегат у Турској (1952-1953), апостолски нунције у: Колумбији (1953-1959), Либану (1959-1960) и Француској (1960-1969). Папа Павле VI га је, 1969, именовао за кардинала. Исте године је именован за префекта Конгрегације за канонизацију светитеља, на чијем челу је био до 1973. Био је и камерленго Римске цркве (1979-1985). Умро је 8. новембра 2001. УП. „La morte del Cardinale Paolo Bertoli”, L'Osservatore Romano 257 (9.11.2001) 4. 
Пелегринетија (Ermenegildo Pellegrinetti) ${ }^{3}$ из Београда, преузео управу ad interim над апостолском нунцијатуром у Светосавској улици у Београду.

Како по службеној дужности, а може се рећи и поучен искуством стеченим поред Пелегринетија, Бертоли је често и веома детаљно обавештавао Свету Столицу о дешавањима у Југославији. Питање Конкордата било је главна тема и проблематика која је заокупљала ватиканско-југословенске односе у том периоду. Неизбежна тема свакако је била и Српска православна црква, посебно након смрти патријарха Варнаве, и период у време интерегнума (јул 1937 - фебруар 1938) и убрзо након њега. Свакако посебно интересовање било је посвећено избору новог поглавара фебруара 1938. године. Будући да су сви министри и посланици православне вероисповести који су гласали за Конкордат били искључени из Српске цркве, то је довело до једне специфичне ситуације, да је било неизводљиво организовати избор новог патријарха. Стога је период интерегнума трајао доста дуго - седам пуних месеци. Да би дошло до избора новог патријарха било је неопходно да се најпре реши конкордатско питање.

За избор новог патријарха владало је велико интересовање које није заобишло ни представника апостолске нунцијатуре у Београду. У јануару и фебруару 1938. Бертоли је често писао свом некадашњем шефу, кардиналу Пелегринетију. Он сам каже у једном од писама да зна да је кардинал добро информисан о свему шта се дешава, јер је добијао југословенску штампу (Бертоли помиње новине Време), ${ }^{4}$ али помиње да му пише из разлога што о свему томе нема са ким да прича у Београду. ${ }^{5}$ Тако је у својој преписци са Пелегринетијем најпре писао о Архијерејском сабору, обавештавајући га, 12. јануара 1938 , да ће 22. јануара бити саборска ванредна седница и да се осећа да су многи уморни услед шестомесечног упражњеног патријарашког трона. ${ }^{6}$ У писму од 25 . јануара 1938. поменуо је да се прича да је Сабор наклоњен хушкању које врше свештеници, те је поставио питање да ли ће доћи до предаје и до компромиса. ${ }^{7}$ O самом заседању, у периоду од 2. до 9. фебруара 1938, Бертоли пише у свом писму Пелегринетију, 2. фебруара 1938, како , ,i nostri fratelli dissidenti” настављају дуге и напорне седнице које ће трајати неколико дана ${ }^{8}$ и преноси гласине да су четири петине Сабора против споразума са Стојадиновићем и поред његових обећања и изјава, у које се убрајају и изјаве свештеника Корошеца. Ватикански дипломата износи став да се Срби и овом приликом служе једним католиком ради својих интереса: „Anche questa volta i serbi si son serviti di un cattolico per tirar il collo

3 Ерменеђилдо Пелегринети (Фонди ди Камајоре, 1876 - Рим, 1943) надбискуп и кардинал Католичке цркве. У дипломатску службу Свете Столице ступио је 1919. када га је Акиле Рати (Achile Ratti) одабрао за секретара при нунцијатури у Пољској. Након избора надбискупа Ратија за папу 1922. године, Пелегринети је изабран за апостолског нунција у Краљевини СХС и именован за титуларног надбискупа Адане. Рукоположен је 18. јуна 1922. у Риму. У Београду је остао на дужности све до именовања за кардинала децембра 1937. Након избора кардинала Пачелија за папу, у Курији није имао великих дужности. Као кардинал у Риму је држао предавања о хришћанском истоку. УП. „†Il Cardinale Ermenegildo Pellegrinetti”, L'Osservatore Romano 74 (31.3.1943) 2; „Pellegrinetti, Ermenegildo, 1876-1943”, y: LeBlanc 2017, 558-560.

4 Бертоли Пелегринетију, [Београд], 25. јануар 1938, у: Archivio Apostolico Vaticano (AAV), Segreteria di Stato (Segr. Stato), Spogli Cardinali e Officiali della Curia (Spogli Curia), Pellegrinetti card. Ermenegildo (Pellegrinetti), busta (b.) 6.

5 Бертоли Пелегринетију, [Београд], 20. фебруар 1938, у: AAV, Segr. Stato, Spogli Curia, Pellegrinetti, b. 6. 6 Бертоли Пелегринетију, [Београд], 12. јануар 1938, у: AAV, Segr. Stato, Spogli Curia, Pellegrinetti, b. 6. 7 Бертоли Пелегринетију, [Београд], 25. јануар 1938, у: AAV, Segr. Stato, Spogli Curia, Pellegrinetti, b. 6. 8 „наша браћа дисиденти.”, Бертоли Пелегринетију, [Београд], 2. фебруар 1938, у: AAV, Segr. Stato, Spogli Curia, Pellegrinetti, b. 6. 
al pollo....".9 О току заседања Архијерејског сабора Бертоли пише Пелегринетију, 7. фебруара 1938, да су епископи тек на трећој тачки дневног реда, као и да постоје две верзије како ће се све завршити: или да ће до измирења доћи или неће. Бертоли, такође, пише да нижи клир не престаје са својим фанатизмом и наставља да узбуњује народ, као и да прети владикама ако дође до мира са Стојадиновићевом владом. По Бертолију постоје и други који мисле да ће доћи до ситуације као у Румунији, што би и буквално довело до диктатуре, за коју каже да је она по њему де факто увек постојала у Југославији. У писму је поменуо и Корошеца за кога наводи да је много укаљао углед, те и да ни у Словенији није радо виђен. ${ }^{10}$ Бертоли је фебруара 1938 . имао сусрет са Корошецем, о коме је писао у извештају државном секретару Свете Столице, кардиналу Пачелију, 23. фебруара 1938. Тема тога разговора била је улога Корошеца у повлачењу Конкордата. Како Бертоли наводи, Корешец је истакао да је морао да се нађе у помоћи свом колеги Стојадиновићу, јер се није могло ићи у бескрај у сукобљавању са Синодом с обзиром да је морао бити изабран патријарх. ${ }^{11}$ О разочарењу услед отказивања од Конкордата и учешћу Корошеца у томе Бертоли је писао и Пелегринетију истакавши да је византинизам Београда и макијавелизам Корошеца превршио сваку меру, као и да то неће лако проћи код папе:

Come vede si sono finalmente svegliati lassù in piccionaia. E difatti il bizantinismo di Belgrado e il macchiavellismo del prete sloveno han passato tutti i limiti. Il Papa pur deve esser arrabbiato e fare che questa volta non la vuol fare passar liscia. Vedesse che misere e viete ragioni ha avuto il coraggio di portar fuori Don Antonio! E pensare che il suo vescovo c'ha creduto! Adesso tocca a me a fare un passo direttamente. Vedremo come andrà. Certo che il momento è brutto e delicato. Fino a ieri a lei dicevano che volevano il Concordato: oggi di fronte ai popi serbi hanno calato le brache e la maschera. Ma che sto a parlar di queste cose con V.E., che le sa meglio di me? Però mi scuserà: qui non c'ho da parlai con nessuno. I croati lo sa come la pensano .... Gli sloveni difendono a tutto spiano il loro prete .... E chi ne soffre è il cattolicesimo puro, che i ciechi adoratori del momento fuggente sacrificano per interessi meschini: e poi si pretende dal Signore la benedizione! ...12

9 „И овога пута Срби су искористили једног католика да извуку пилету главу....”. Бертоли Пелегринетију, [Београд], 2. фебруар 1938, у: AAV, Segr. Stato, Spogli Curia, Pellegrinetti, b. 6.

10 Бертоли Пелегринетију, [Београд], 7. фебруар 1938, у: AAV, Segr. Stato, Spogli Curia, Pellegrinetti, b. 6. 11 Бертоли Пачелију, Београд, 23. фебруар 1938, бр. 20617 (779/38), у: Archivio Storico della Segreteria di Stato, Sezione per i Rapporti con gli Stati (ASRS), Fondo Archivio della Congregazione degli Affari Ecclesiastici Straordinari (AA.EE.SS.), Pio XI, Jugoslavia, Posizione (Pos.) 96, Posizione Originale (P.O.), fascicolo (fasc.) 67, fogli (ff.) 32v-33r.

12 „Као што видите, коначно су се пробудили тамо горе у голубарнику. Заправо су византинизам Београда и макијавелизам словеначког свештеника прешли сваку границу. Папа чак мора бити љут и овога пута не сме да допусти да прође тек тако. Кад бисте видели какве је јадне и бајате разлоге дао дон Антон. И мислити да му је у то његов бискуп поверовао. Сада следује да ја учиним одлучујући корак. Видећемо како ће ићи. Свакако да је тренутак ружан и деликатан. До јуче су Вама говорили да желе Конкордат, а данас пред српским поповима скидају панталоне и маске. Шта ја Вашој екселенцији говорим о овим стварима, кад Ви то знате боље од мене? Али ипак ми опростите: овде нисам имао никога да о томе причам. Знате како мисле Хрвати .... Словенци бране свом снагом њиховог свештеника .... И ко ту страда, то је чисто католичанство, које слаби обожаваоци пролазног тренутка жртвују због ситних интереса, а после се очекује благослов од Господа! ...” Бертоли Пелегринетију, [Београд], 20. фебруар 1938, у: AAV, Segr. Stato, Spogli Curia, Pellegrinetti, b. 6. 
Након скидања ескомуникације са министара и посланика од стране Светог архијерејског сабора, Бертоли је, 14. фебруара 1938, послао Пачелију то саборско саопштење од 11. фебруара. Како наводи Бертоли, тиме су односи Српске цркве и Стојадиновићеве владе враћени у нормалу. Бертоли напомиње да ће епископи мирно моћи да мисле о избору новог патријарха и да више ништа не кочи да Влада узме учешће у самом избору. ${ }^{13}$ Такође, износи став да ће након избора патријарха Стојадиновић са задовољством изаћи из једне дуге борбе у којој је претрпео велика понижења. ${ }^{14}$ Поред Стојадиновића, ватикански дипломата је дао став и о Српској цркви: „Pure la Chiesa serboortodossa, ne uscirà contenta di aver vinto una battaglia contro i cattolici e di aver affermato la sua intransigenza sulla nuova Jugoslavia."15

Бертоли је у свом извештају од 14. фебруара 1938. кардиналу Пачелију навео и тројицу кандидата за новог српског патријарха: црногорског митрополита Гаврила Дожића, кога је окарактерисао као владиног присталицу, ${ }^{16}$ напрасног и слабог расположења према католицима, затим сарајевског митрополита Петра Зимоњића, кога назива мирољубивим старим епископом, и новосадског епископа Иринеја Ћирића, за кога је рекао да је човек европске културе и расположен према католицима. ${ }^{17}$ Поред имена кандидата Бертоли обавештава Пачелија и о томе да је Архијерејски сабор желео да измени начин избора патријарха због великог уплива лаика на избор, али да је Влада успела да убеди епископе да се то помери за неко друго време, обећавши своју подршку. Услед тога, како наводи Бертоли, није било више препрека за избор патријарха, чиме је Влада избегла да у скупштини дође до расправе око тог евентуалног закона, који би опозиција искористила у борби против Стојадиновића. ${ }^{18}$ Извештај од 14. фебруара Бертоли завршава речима о владици Николају окарактерисавши га као најљућег антикатолика који није желео да прихвати договор са Владом и који је напустио седнице Сабора, где је запретио расколом. Бертоли преноси гласине да је могуће да ће бити смењен. ${ }^{19}$ Исте вести које је послао државном секретару о жељама српских епископа о изменама у закону о избору патријарха, као и о владици Николају, Бертоли је истог дана упутио и кардиналу Пелегринетију. ${ }^{20}$

13 Бертоли Пачелију, Београд, 14. фебруар 1938, бр. 20580 (691/38), у: ASRS, AA.EE.SS., Pio XI, Jugoslavia, Pos. 96, P.O., fasc. 67, f. 14v.

14 Бертоли Пачелију, Београд, 14. фебруар 1938, бр. 20580 (691/38), у: ASRS, AA.EE.SS., Pio XI, Jugoslavia, Pos. 96, P.O., fasc. 67, f. 14v.

15 „И Српска православна црква ће такође изаћи задовољна будући да је победила битку против католика и да је потврдила своју непопустљивост над новом Југославијом.” Бертоли Пачелију, Београд, 14. фебруар 1938, бр. 20580 (691/38), у: ASRS, AA.EE.SS., Pio XI, Jugoslavia, Pos. 96, P.O., fasc. 67, f. $14 \mathrm{v}$.

16 Стојадиновић у свом дневнику пише како је настојао да за патријарха буде изабран човек са којим би могао да сарађује по питањима од заједничког интереса по државу и цркву. Он помиње да је онда почела и већина архијереја да гледа на ту ствар реалније и да су истакли митрополита Гаврила Дожића као кандидата знајући да ће га он подржати. Сам Стојадиновић помиње како је позвао министре из Владе да гласају за Гаврила Дожића. Уп. Стојадиновић 1963, 543.

17 Бертоли Пачелију, Београд, 14. фебруар 1938, бр. 20580 (691/38), у: ASRS, AA.EE.SS., Pio XI, Jugoslavia, Pos. 96, P.O., fasc. 67, f. 14v.

18 Бертоли Пачелију, Београд, 14. фебруар 1938, бр. 20580 (691/38), у: ASRS, AA.EE.SS., Pio XI, Jugoslavia, Pos. 96, P.O., fasc. 67, f. 14v.

19 Бертоли Пачелију, Београд, 14. фебруар 1938, бр. 20580 (691/38), у: ASRS, AA.EE.SS., Pio XI, Jugoslavia, Pos. 96, P.O., fasc. 67, f. 14v.

20 Бертоли Пелегринетију, [Београд], 14. фебруар 1938, у: AAV, Segr. Stato, Spogli Curia, Pellegrinetti, b. 6. 
Како се ближио изборни сабор Бертоли је и о томе писао свом уваженом пријатељу Пелегринетију. Тако, 18. фебруара, напомиње да у избору чак учествује, само зато што је председник Државног савета, и Стеван Сагадин, кога је назвао отпадником и другобрачним човеком. ${ }^{21}$ Поред тројице кандидата о којима је писао и Пачелију, 14. фебруара, овога пута је напоменуо да можда постоји могућност и за евентуалног четвртог кандидата. ${ }^{22}$ Дан пре избора патријарха, Бертоли пише Пелегринетију: „Domani verrà eletto il Patriarca e speriamo che lo Spirito Santo li illuminò. Fatto quello il Governo respirerà di più da una parte e forse troverà la maniera di accomodarsi coll'altra: ma bisognerà star duri."23

О избору митрополита Гаврила Дожића2 24 за новог патријарха 21. фебруара 1938. године ${ }^{25}$ Бертоли је након два дана, 23. фебруара 1938, известио кардинала Пачелија. Ватикански дипломата је навео да је избор обављен по правилнику из 1930. године, да је изборни сабор био сачињен од 60 чланова, од којих је 40 било црквених, а 20 цивилних, и да се у подне гласало између шест кандидата, које је претходно изабрао Архијерејски cабор:

Ieri l'altro, 21, secondo il cerimoniale previsto dal Regolamento del 1930, si radunò nella Chiesa Cattedrale il Concilio elettorale, composto questa volta di 60 membri - 40 ecclesiastici e 20 laici - per procedere alla nomina del nuovo Patriarca serbo-ortodosso. A mezzogiorno il Concilio aveva votato la terna tra i sei precedentemente designati dal Concilio Episcopale e pochi minuti dopo i Reggenti firmavano l'Ukaz, col quale nominavano Patriarca della Santa Chiesa Serbo-ortodossa il metropolita del Montenegro e del Primorie il Dr. Gavrilo (Gabriele) Dožić, che aveva riportato la maggioranza di voti.

La votazione si è svolta regolarmente e vi hanno preso oltre i vescovi e le altre personalità ecclesiastiche aventi il diritto di voto, i ministri del Governo ortodossi, il Rettore dell'Università di Belgrado ecc.. Mancavano, in segno di protesta, due vescovi: Nikolao Velimirović e Jreneo Djordjević, che con tanto furore avevano capeggiato la campagna contro il Concordato. ${ }^{26}$

21 Бертоли Пелегринетију, [Београд], 18. фебруар 1938, у: AAV, Segr. Stato, Spogli Curia, Pellegrinetti, b. 6.

22 Бертоли Пелегринетију, [Београд], 18. фебруар 1938, у: AAV, Segr. Stato, Spogli Curia, Pellegrinetti, b. 6.

23 „Сутра ће бити изабран патријарх и надајмо се да их је Свети Дух просветлио. Завршивши ово Влада ће боље да продише са једне стране, и могуће да ће наћи начина да се прилагоди са друге: али потребно је бити чврст.” Бертоли Пелегринетију, [Београд], 20. фебруар 1938, у: AAV, Segr. Stato, Spogli, Pellegrinetti, b. 6.

24 Гаврило Дожић (Доња Морача, 1881 - Београд, 1950) патријарх српски. Школовао се у Београду и у Атини где је 1905. и докторирао. Био је митрополит рашко-призренски (1911-1913), пећки (19131920), а након васпостављања Српске патријаршије изабран је за црногорско-приморског митрополита (1920-1938). Учестовао је на Свеправославном саветовању, 1923, у Цариграду. Био је мјестобљуститељ патријарашког трона (1930) и кандидат за патријарха 1930. Након избијања Другог светског рата био је ухапшен и интерниран у манастирима Љубостињи и Војловици. Био је заточен и у логору Дахау. Вратио се у Југославију 14. новембра 1946. Умро је 7. маја 1950. УП. Живојиновић (2006), 570-573; Радић 2011².

25 О избору патријарха видети: „Избор новог Патријарха Српске Православне Цркве”, ГСПП 7 (1938) 119-122; „Митрополит црногорски г. др. Гаврило Дожић изабран за новог Патријарха”, Време 5783 (22.2.1938) 1, 5-7; „Избор патријарха Српске православне цркве”, Политика 10684 (22.2.1938) 3-4.

26 „Прекјуче, 21, по церемонији предвиђеној Правилником из 1930, окупио се у Саборној цркви изборни сабор, сачињен овога пута од 60 чланова - 40 црквених и 20 лаика - како би обавили именовање новог српског православног патријарха. У подне је Сабор гласао за тројицу од 
Бертоли даље наводи и кратку биографију новог патријарха где је дао основне податке где је студирао, када је и на који начин постао епископ:

Il nuovo patriarca è nato nel Montenegro il 17 Maggio del 1881. Dopo aver fatto gli studi a Belgrado e a Prizren si fece monaco, passò a seguito a Costantinopoli e di lì nel 1905 ad Atene dove quattro anni dopo conseguiva la laurea in teologia. Fino al 1910 rimase al monastero di Hilendar al Monte Athos, quindi fece viaggi di istruzione in Svizzera e in Francia e alla fine del 1911 fu nominato vescovo di Prizren, grazie alle mene, si dice fatte da lui a Costantinopoli presso la Sublime Porta (Prizren faceva ancora parte dall'impero turco). Dalla sede di Prizren passava alla sede metropolitana di Peć finchè nel 1921 veniva trasferito a Cettigne a reggere la chiesa metropolitana del Montenegro.

Varie volte ha rappresentato all'estero la chiesa serbo-ortodossa ed ha lavorato per la legislazione ortodossa a varie riprese. ${ }^{27}$

Бертоли је у извештају описао и патријархово устоличење, ${ }^{28}$ које је обављено сутрадан по избору, 22. фебруара 1938. године, као и патријархов говор:

Ieri si è proceduto alla intronizzazione solenne presenti i Reggenti, il Governo, le altre autorità ecclesiastiche, militari e civili, e una buona rappresentanza del Corpo Diplomatico. Nella breve allocuzione il nuovo Patriarca ha esaltato la missione spirituale della Chiesa Serba e più ancora quella nazionale nella vita di tutto il popolo, che ha condotto alla gloria attraverso le secolari lotte. Egli promette di continuarne le gloriose tradizioni: "la Chiesa serbo-ortodossa largamente professa l'amore, la fratellanza, l'unione, la forza, ......... e l'uguaglianza con tutti gli altri abitanti della nostra grande patria, poichè ci unisce la fratellanza e il sangue, il sangue slavo." ${ }^{29}$

шесторице раније од Архијерејског сабора одређених кандидата, и након неколико минута намесници су потписали указ којим су за новог патријарха Свете српске православне цркве именовали митрополита Црне Горе и Приморја Др Гаврила Дожића, који је имао већину гласова.

Гласање је обављено регуларно и учешће су узели поред епископа и друге црквене личности које су имале право гласа, православни министри из Владе, ректор универзитета итд. У знак протеста, фалила су двојица епископа: Николај Велимировић и Иринеј Ђорђевић, који су са великим бесом предводили кампању против Конкордата.” Бертоли Пачелију, Београд, 23. фебруар 1938, бр. 20616 (780/38), y: ASRS, AA.EE.SS., Pio XI, Jugoslavia, Pos. 115, P.O., fasc. 79, f. 68r.

27 „Нови патријарх је рођен у Црној Гори 17. маја 1881. По завршетку студија у Београду и Призрену, замонашио се, а потом је отишао у Цариград, а одатле 1905. године у Атину, где је четири године касније стекао диплому теологије. До 1910. године боравио је у манастиру Хиландар на Светој Гори, затим је ишао на студијска путовања у Швајцарску и Француску, а крајем 1911. именован је за призренског епископа, захваљујући интригама, које је како се прича чинио на Великој порти током боравка у Цариграду (Призрен је још био део Турског царства). Са призренске катедре прешао је на пећку катедру, све док 1921. године није премештен на Цетиње да управља Митрополијом црногорском.

Неколико пута је представљао Српску православну цркву у иностранству и у разним приликама радио око православног законодавства.”, Бертоли Пачелију, Београд, 23. фебруар 1938, бр. 20616 (780/38), y: ASRS, AA.EE.SS., Pio XI, Jugoslavia, Pos. 115, P.O., fasc. 79, f. 68r.

28 О патријарховом устоличењу видети: „Свечано устоличење Његове Светости Патријарха српског Господина Д-р Гаврила”, ГСПП 7 (1938) 122-128; „Устоличење патријарха Гаврила”, у Време 5784 (23.2.1938) 1, 4-7; „Јуче је на свечан начин устоличен нови Патријарх Српске православне цркве”, Политика 10685 (23.2.1938) 1-2; „Његова Светост Гаврило нови патријарх Српске православне цркве”, Београдске општинске новине, 2 (1938) 107-111.

29 „Јуче је настављено са свечаним устоличењем на коме су били присутни намесници, Влада, остали црквени, војни и цивилни великодостојници, са великим бројем представника дипломатског 
Бертоли је описао патријарха Гаврила као човека тврдог и грубог карактера, који не ужива велике симпатије: „Di carattere dicono che sia duro, anzi grossolano e poco abbordabile, tanto vero che non gode grandi simpatie." ${ }^{30}$ Неизоставан део извештаја, посебно у том периоду конкордатске проблематике био је став новог патријарха о Конкордату и католицима. Бертоли подвлачи да се Гаврило Дожић по том питању држао са стране и да је био помирљив према Влади, као и да је у начелу сматрао да и Католичка црква има право на слободу, али да ипак није био расположен према Конкордату. ${ }^{31}$ По ставу ватиканског дипломате, митрополит Дожић је знао да игра добро међу различитим партијама тако да је остао persona grata и Влади и Двору, и да је на тај начин успео да постане патријарх, иако није био најомиљенији међу свештенством. Због тога Бертоли износи став да се и приликом избора новог поглавара показала потчињеност Српске цркве политичком елементу у земљи. ${ }^{32}$ Став о патријарховом односу према католицима Бертоли завршава речима да патријарх Гаврило према њима нема много симпатија, те да му се чини да им није много наклоњен, као и да ће наредно време показати ставове према Католичкој цркви са нове позиције коју је заузео. ${ }^{33}$

Бертоли је 24. фебруара 1938. писао и Пелегринетију о избору патријарха истакавши како је изабран кандидат кога је Влада желела. Поред тога, напоменуо је да му је министар Корошец рекао да се Влада нада да ће успети да замени неке епископе из Синода. ${ }^{34}$ Део писма Пелегринетију говори и о и епископима Николају и Иринеју који нису узели учешћа на Сабору као и реакцији против новог патријарха:

Nikolao e Ireneo Djordjević non erano presenti alla elezione: Ireneo anzi mandò una lettera di protesta. Il giorno della nomina di Dožić usci subito un foglietto contro di lui. Ma ormai la partita degli arrabbiati è persa. Rinfacciano a Dožić che non sia pienamente nazionale perché nel 1911 diventò vescovo di Prizren, grazie a suoi intrighi fatti a Costantinopoli, contro il candidato che avrebbe desiderato il governo di Belgrado. ${ }^{35}$

кора. У кратком обраћању нови патријарх је величао духовну мисију Српске цркве и још више ону националну у народном животу, што је током вековних борби довела до славе. Он обећава да ће наставити славну традицију: „Српска православна црква широко исповеда љубав, братство, јединство, снагу, ......... и једнакост са свима другим становницима наше велике отаџбине, јер нас уједињује братство и крв, словенска крв.” Бертоли Пачелију, Београд, 23. фебруар 1938, бр. 20616 (780/38), y: ASRS, AA.EE.SS., Pio XI, Jugoslavia, Pos. 115, P.O., fasc. 79, f. 68rv.

30 „По карактеру кажу да је тврд, чак и груб и слабо приступачан, чак толико да не ужива велике симпатије.” Бертоли Пачелију, Београд, 23. фебруар 1938, бр. 20616 (780/38), у: ASRS, AA.EE.SS., Pio XI, Jugoslavia, Pos. 115, P.O., fasc. 79, f. 68r.

31 Бертоли Пачелију, Београд, 23. фебруар 1938, бр. 20616 (780/38), у: ASRS, AA.EE.SS., Pio XI, Jugoslavia, Pos. 115, P.O., fasc. 79, f. 69r.

32 Бертоли Пачелију, Београд, 23. фебруар 1938, бр. 20616 (780/38), у: ASRS, AA.EE.SS., Pio XI, Jugoslavia, Pos. 115, P.O., fasc. 79, f. 69r.

33 Бертоли Пачелију, Београд, 23. фебруар 1938, бр. 20616 (780/38), у: ASRS, AA.EE.SS., Pio XI, Jugoslavia, Pos. 115, P.O., fasc. 79, f. 69r.

34 Бертоли Пелегринетију, [Београд], 24. фебруар 1938, у: AAV, Segr. Stato, Spogli Curia, Pellegrinetti, b. 6.

35 „Николај и Иринеј Ђорђевић нису били присутни на избору: Иринеј је чак послао једно протесно писмо. У дану када је именован Дожић одмах је изашао један лист против њега. Али игра оних који се љуте је већ изгубљена. Дожићу замерају да није у потпуности патриота, јер је 1911. постао епископ у Призрену захваљујући својим интригама у Цариграду против кандидата кога је желела Влада из Београда". Бертоли Пелегринетију, [Београд], 24. фебруар 1938, у: AAV, Segr. Stato, Spogli Curia, Pellegrinetti, b. 6. 
Паоло Бертоли је 1938. премештен на дипломатску службу у нунцијатуру у Париз. У јуну 1938. у Београд је дошао нови апостолски нунције Еторе Феличи (Ettore Felici). ${ }^{36}$ Феличију Југославија није била непозната јер је био сарадник како првог нунција Франческа Керубинија (Francesco Cherubini), ${ }^{37}$ тако и Пелегринетија. У инструкцијама датим новом нунцију пре поласка на нову дужност, Државни секретаријат Свете Столице је дао и свој став о Српској цркви истакавши њен, како кажу - огроман, утицај на режим и стављајући акценат на лош положај Католичке цркве у Југославији:

L'influsso della Chiesa ufficiale serba sul regime è enorme a tutto discapito della religione cattolica contro la quale professa pubblicamente, come ben si è veduto nella recente lotta contro il Concordato l'odio più cieco e fanatico. In tale circostanza la Chiesa serba non ha avuto ritegno di allearsi con i Comunisti contro la "dominazione della Chiesa di Roma". In linea di diritto i culti "riconosciuti" godono secondo la Costituzione del 3 Novembre 1931, "parità giuridica", di fronte allo Stato; ma in linea di fatto, ancor oggi i cattolici si trovano in una vera condizione di inferiorità, resa più acuta dalla circostanza che mentre, nel frattempo, (1931-1934) le altre confessioni religiose, hanno sistemato i loro rapporto con lo Stato per mezzo di "Regolamenti" i cattolici, che giustamente contavano sul Concordato, sono rimasti delusi sicchè sono tuttora in attesa di una sistemazione giuridica. ${ }^{38}$

За новог нунција разматрано је и питање Конкордата, где му је речено да се то питање највероватније уопште неће ни покретати у наредним годинама, док се држава не

36 Еторе Феличи (Сењи, 1881 - Даблин, 1951) надбискуп Католичке цркве. Дипломатску службу Свете Столице започео је у Апостолској нунцијатури у Краљевини СХС (1920-1925), затим у Португалу (1925-1927). У нунцијатури у Чилеу најпре је био отправник послова (1927), а затим и апостолски нунције (1927-1938). За титуларног надбискупа коринтског именован је 9. новембра 1927, а рукоположен 30. децембра 1927. у Сантијаго де Чилеу. Био је апостолски нунције у Југославији (1938-1941), а након окупације Југославије вратио се у Рим, где је био у Државном секретаријату Свете Столице све до одласка на дужност апостолског нунција у Ирску 1949. где је остао до смрти 1951. УП. Valenzi 2011; „Dal Cile. La solenne consacrazione episcopale del Nunzio Apostolico Mons. Felici”, L'Osservatore Romano 27 (2.2.1928) 1.

37 Франческо Керубини (Соријано дел Чимино, 1865 - Рим, 1934) надбискуп Католичке цркве. Био је члан Апостолске пенитенцијарије (1904-1909), подсекретар Конгрегације за монаштво. Дипломатску службу Свете Столице започео је на Хаитију најпре као апостолски делегат (19151916), а затим као интернунције (1916-1920). Именован је за надбискупа Никозије новембра 1915, а рукоположен у Риму, 13. децембра 1915. Био је први апостолски нунције у Краљевини СХС (19201922). Након оставке на дужност, вратио се у Рим где је био каноник у Базилици светог Петра. УП. Pięta 2002, 272; „Consacrazioni episcopali”, L'Osservatore Romano 344 (13.12.1915) 2; „La morte di Mons. Cherubini", L'Osservatore Romano 85 (13.4.1934) 2.

38 „Утицај званичне Српске цркве на режим је огроман на штету католичке вере против које се јавно изјашњава, када се добро видела веома слепа и фанатична мржња у недавној борби против Конкордата. У тим околностима, Српска црква се није уздржала да се удружи са комунистима против „доминације Римске цркве”. У складу са законом, „признати” култови уживају, према Уставу од 3. новембра 1931, „правни паритет”, пред државом; али у ствари, чак и данас се католици налазе у правом стању инфериорности, заоштрене околношћу да, док су у међувремену (1931-1934) остале верске конфесије свој однос са државом уредиле путем „уредби”, католици, који су с правом рачунали на Конкордат, били су разочарани тако да још увек чекају правно решење.” Istruzioni per Sua Eccellenza Rev.ma Monsignor Ettore Felici, Arcivescovo titolare di Corinto, Nunzio Apostolico in Jugoslavia, 17 Giugno 1938, бp. 2245/38 y: ASRS, AA.EE.SS., Pio XI, Jugoslavia, Pos. 125, P.O., fasc. 83, ff. $13 r-14 r$. 
ослободи утицаја „шизматичке” цркве и док на власт не дође владар који, као краљ Александар, не буде могао да је контролише:

Dopo ciò che è accaduto sembra evidente che non si può per ora pensare alla ripresa dei contatti col Governo per la ratifica del Concordato.

Un atto pubblico e solenne, di valore internazionale e di un ambito così esteso da regolare in tutta la loro ampiezza i rapporti tra la Chiesa e lo Stato, qual'è il Concordato, probabilmente non sarà possibile in Jugoslavia per vari anni, finchè cioè il Governo non si sarà liberato dalla vera dominazione che su di esso esercita la chiesa scismatica o non potrà poggiarsi su l'autorità di un Sovrano che domini le pretese della predetta confessione religiosa, quale era per es. il defunto Re Alessandro, caldeggiatore del Concordato medesimo. Per ora le probabilità in tal senso sono scarse.

Il Nunzio Apostolico, tuttavia, soprattutto col Governo attuale che ha subito l'umiliazione di dover rinnegare ciò che prima aveva pubblicamente approvato, potrà adoperarsi con molto tatto e accortezza per sfruttare il disagio in cui si trovano gli Uomini di Governo e destare in essi sentimenti di dignità politica compromessa dai fatti suaccennati, in vista di spingerli a trovare qualche rimedio alla situazione assurda in cui si sono posti dinanzi al mondo civile. In questa indiretta azione del Nunzio apostolico è sperabile che scaturisca qualche buona reazione alle ingerenze, veramente inconcepibili, della Chiesa scismatica nell'azione politica del Governo e ne sia diminuito l'influsso. ${ }^{39}$

Ни током службовања нунција Феличеа однос Католичке и Православне цркве није се знатно променио. Специфична политичка и религијска ситуација у Југославији није била наклоњена добром односу двеју Цркава које су тежиле да осигурају свој утицај и снагу у земљи како би вршиле своју мисију. Делиле су мање-више исти простор, али не и исте ставове по многим питањима, тако да су велике разлике учиниле да једни друге гледају са великом резервом и не у тако лепом светлу.

39 „После онога што се догодило, чини се јасним да за сада није могуће размишљати о поновном успостављању контаката са Владом ради ратификације Конкордата.

Јавни и свечани акт, од међународног значаја и тако широког опсега да регулише односе између Цркве и државе у свој њиховој ширини, попут Конкордата, вероватно неће бити могућ у Југославији за неколико година, односно док се Влада не ослободи праве доминације коју шизматичка црква над њом врши или док се не буде ослонила на ауторитет владара који ће да управља захтевима горе наведене верске конфесије, као што је био нпр. покојни краљ Александар, заговорник истог Конкордата. За сада су у том смислу мале шансе.

Апостолски нунције, међутим, посебно са садашњом Владом која је претрпела понижење што мора да порекне оно што је претходно јавно одобрила, моћи ће са великим тактом и оштроумношћу да искористи нелагоду у којој се налазе људи из Владе и побудити у њима осећања политичког достојанства угроженог поменутим чињеницама, како би их натерао да пронађу неки лек за апсурдну ситуацију у којој су се нашли пред цивилизованим светом. У овом индиректном деловању апостолског нунција може се надати да ће доћи до неке добре реакције на заиста незамисливо мешање шизматичке Цркве у политичко деловање Владе и да ће њен утицај бити смањен.” Istruzioni per Sua Eccellenza Rev.ma Monsignor Ettore Felici, Arcivescovo titolare di Corinto, Nunzio Apostolico in Jugoslavia, 17 Giugno 1938, бp. 2245/38 y: ASRS, AA.EE.SS., Pio XI, Jugoslavia, Pos. 125, P.O., fasc. 83, f. $31 \mathrm{r}$. 


\section{Извори}

\section{Необјављени извори:}

Archivio Apostolico Vaticano (AAV)

Archivio della Nunziatura in Jugoslavia (Arch. Nunz. Jugoslavia)

busta 2

busta 9

Segreteria di Stato (Segr. Stato)

Spogli Cardinali e Officiali della Curia (Spogli Curia)

Pellegrinetti card. Ermenegildo (Pellegrinetti)

busta 6 (numero provvisorio) [привремени број]

(ASRS)

Archivio Storico della Segreteria di Stato, Sezione per i Rapporti con gli Stati

Fondo Archivio della Congregazione degli Affari Ecclesiastici Straordinari (AA.EE.SS.)

Pio XI

Jugoslavia

Pos. 96, P.O., fasc. 67

Pos. 115, P.O., fasc. 79

Pos. 125, P.O., fasc. 83

\section{Објављени извори}

Мемоари патријарха српског Гаврила, 1974, Париз: [Richelieu].

Stojadinović, Milan M. (1963), „Ni rat ni pakt. Jugoslavija izmedju dva rata“, Buenos Ajres: El Economista.

\section{Литература}

А.В., „Велика црквено-народна свечаност у Пећи”, Гласник Српске православне naтријариије 20-21 (1938) 528-534.

„Consacrazioni episcopali”, L'Osservatore Romano 344 (13.12.1915) 2.

„Dal Cile. La solenne consacrazione episcopale del Nunzio Apostolico Mons. Felici”, L'Osservatore Romano 27 (2.2.1928) 1.

„†Il Cardinale Ermenegildo Pellegrinetti”, L’Osservatore Romano 74 (31.3.1943) 2.

„Избор новог Патријарха Српске Православне Цркве”, Гласник Српске православне патријариије 7 (1938) 119-122.

„Избор патријарха Српске православне цркве”, Политика 10684 (22.2.1938) 3-4.

„Јуче је на свечан начин устоличен нови Патријарх Српске православне цркве”, Политика 10685 (23.2.1938) 1-2.

„La morte del Cardinale Paolo Bertoli”, L'Osservatore Romano 257 (9.11.2001) 4.

„La morte di Mons. Cherubini”, L'Osservatore Romano 85 (13.4.1934) 2.

LeBlanc, Jean, (2017): D’Agagianian à Wyszynski: dictionnaire biographique des cardinaux de la première moitié du XXe siècle (1903-1958), Montréal - Ottawa, Wilson \& Lafleur, 558-560. 
Mithans, Gašper, (2017): Jugoslovanski konkordat. Pacem in discordia ali jugoslovanski ,kulturkampf“, Ljubljana: Inštitut za novejšo zgodovino Slovenije.

„Митрополит црногорски г. др. Гаврило Дожић изабран за новог Патријарха”, Време 5783 (22.2.1938) 1, 5-7.

„Његова Светост Гаврило нови патријарх Српске православне цркве”, Београдске опитинске новине 2 (1938) 107-111.

„Његова Светост Патријарх српски Господин Д-р Гаврило - Живот и рад Његове Светости", Гласник Српске православне патријариије 7 (1938) 129-131.

Pięta, Zeno (2002): Hierarchia catholica medii et recentioris aevi. Sive summorum pontificum, S.R.E. cardinalium ecclesiarum antistitum series e documentis tabularii praesertim Vaticani collecta, digesta, edita, IX, A Pontificatu Pii PP. X (1903) usque ad Pontificatum Benedicti PP. XV (1922), Patavii: Typis et sumptibus Domus Editorialis „Il Messaggero di S. Antonio".

Radić, Radmila, (1995): „Povratak patrijarha Gavrila Dožića”, Istorija 20. veka 1 (1995) 95-109.

Radić, Radmila (2009): „Izbori patrijarha Srpske pravoslavne crkve u 20. veku”, Istorija 20. veka, 1 (2009), 17-36.

Радић, Радмила (2011²): Живот у временима: патријарх Гаврило (Дожић) 18811950., Београд: Православни богословски факултет.

Salmič, Igor (2015): Al di là di ogni pregiudizio. Le trattative per il concordato tra la Santa Sede e il Regno dei Serbi, Croati e Sloveni/Jugoslavia e la mancata ratifica (1922-1938), Roma: Gregorian \& Biblical Press.

Слијепчевић, Ђоко (1966): Историја Српске православне иркве, II. Од почетка ХІХ века до краја Другог светског рата, Минхен: Искра.

„Свечано устоличење Његове Светости Патријарха српског Господина Д-р Гаврила”, Гласник Српске православне патријаршије 7 (1938) 122-128.

„Устоличење патријарха Гаврила”, Време 5784 (23.2.1938) 1, 4-7.

Valente, Massimiliano (2012): Diplomazia Pontificia e Regno dei Serbi, Croati e Sloveni (1918-1929), Split: Filozofski fakultet - Odsjek za povijest.

Valenzi, Valeriano (2011): S. E. Ettore Felici, Arcivescovo di Corinto, nunzio apostolico, Segni:

Живојиновић, Драгољуб, „Дожић, Гаврило, (Ђорђе)”, Српски биографски речник 2, Нови Сад: Матица Српска, 570-573. 


\section{VATICAN DIPLOMAT PAOLO BERTOLI ON THE ELECTION OF THE SERBIAN PATRIARCH IN 1938}

After the departure of the Apostolic Nuncio Pellegrinetti from Belgrade in December 1937, Paolo Bertoli took over the administration ad interim of the nunciature in Yugoslavia, who, like Pellegrinetti, left his observations and impressions of many events throughout the Kingdom, including the Serbian Orthodox Church. The most significant event during his administration as nunciature was the election of a new patriarch in February 1938.

This paper uses reports and letters to Secretary of State Pacelli, as well as unpublished Bertoli's letters to Cardinal Pellegrinetti in Rome, in which he talks about the Serbian Orthodox Church election assembly, candidates and the personality of the new patriarch Gavrilo Dožić, and in which he is expressing his rather negative opinion motivated by the bad relations with the Serbian Orthodox Church due to the concordat. 